\title{
Erratum to: Introduction to the Special Issue: Subgroup Analysis in Prevention and Intervention Research
}

\author{
Lauren H. Supplee • Brendan C. Kelly • \\ David P. MacKinnon • Meryl Yoches Barofsky
}

Published online: 16 April 2013

(C) Society for Prevention Research 2013

Erratum to: Prev Sci (2013) 14:107-110

DOI 10.1007/s11121-012-0335-9

The original version of this article unfortunately contained mistakes. The name of "David P. MacKinnon" is now corrected in the author group of this article. Also, the affiliations of David P. MacKinnon and Meryl Yoches Barofsky are now corrected.

The online version of the original article can be found at http:// dx.doi.org/10.1007/s11121-012-0335-9.

L. H. Supplee $(\bowtie) \cdot$ B. C. Kelly

Office of Planning, Research and Evaluation, Administration for

Children and Families, 370 L'Enfant Promenade SW, 7th Fl West,

Washington, DC 20447, USA

e-mail: lauren.supplee@acf.hhs.gov

D. P. MacKinnon

Department of Psychology, Arizona State University,

950 S. McAllister, Room 237,

Tempe, AZ 85287-1104, USA

M. Y. Barofsky

University of Maryland, College Park, MD, USA 